\title{
Spirochaeta alkalica sp. nov., Spirochaeta africana sp. nov., and Spirochaeta asiatica sp. nov., Alkaliphilic Anaerobes from the Continental Soda Lakes in Central Asia and the East African Rift
}

\author{
T. N. ZHILINA, ${ }^{1 *}$ G. A. ZAVARZIN, ${ }^{1}$ F. RAINEY, ${ }^{2}$ V. V. KEVBRIN, ${ }^{1}$ \\ N. A. KOSTRIKINA, ${ }^{1}$ AND A. M. LYSENKO ${ }^{1}$ \\ Institute of Microbiology RAS, 117811 Moscow, Russia, ${ }^{1}$ and Deutsche \\ Sammlung von Mikroorganismen und Zellkulturen $\mathrm{GmbH}$, \\ D-38124 Braunschweig, Germany ${ }^{2}$
}

\begin{abstract}
During a study of microbial communities in athalassic bodies of water, three new species within the genus Spirochaeta were described. These are alkaliphilic Spirochaeta alkalica sp. nov. Z-7491 (DSM 8900) and halophilic S. africana sp. nov. Z-7692 (DSM 8902) from the soda-depositing Lake Magadi in Central Africa and haloalkaliphilic $S$. asiatica sp. nov. Z-7591 (DSM 8901) from Lake Khatyn, Central Asia. These mesophilic spirochetes develop at $\mathrm{pHs}$ of $>9$ as anaerobic saccharolytic dissipotrophs. The DNA base compositions (moles percent $\mathrm{G}+\mathrm{C}$ ) of the strains were as follows: $S$. alkalica Z-7491, 57.1; S. africana Z-7692, 56.1; and $S$. asiatica Z-7591, 49.2. The optimum growth parameters (temperature, $\mathrm{pH}$, and $\mathrm{NaCl}$ concentration [percent, wt/vol], respectively) were as follows: for $S$. alkalica $\mathrm{Z}-7491,35^{\circ} \mathrm{C}, 9.2$, and 5 to $7 \%$; for $S$. africana $\mathrm{Z}-7692,35^{\circ} \mathrm{C}, 9.3$, and 5 to $7 \%$; and for $S$. asiatica $Z-7591,35^{\circ} \mathrm{C}, 8.9$, and 3 to $6 \%$. The products of glucose fermentation were acetate, hydrogen, ethanol, and lactate, in different proportions, for $S$. alkalica and $S$. africana; for $S$. asiatica, they were acetate, ethanol, and lactate. $S$. asiatica is strictly anaerobic, while $S$. alkalica and $S$. africana are rather aerotolerant. All three species group within the radiation of the majority of the species of the genus Spirochaeta. Studies of the genes encoding 16S rRNA indicate a possible fanning out of the phylogenetic tree of spirochetes.
\end{abstract}

The genus Spirochaeta represents a group of dissipotrophic (i.e., utilizing low-molecular-weight compounds dissipating from the sites of their origin [29]) saccharolytic bacteria associated with decomposition of (poly) carbohydrates in aquatic habitats. The spirochetes form a fairly coherent group (3) belonging to a separate phylogenetic lineage which correlates with their distinctive morphology $(18,21)$. Members of the genus Spirochaeta exist in diverse environments; however, they still exhibit marked similarities in growth substrate preferences. All species of Spirochaeta utilize carbohydrates and exhibit restricted hydrolytic activity. They utilize soluble hexoses, disaccharides, and pentoses released by polysaccharide-degrading microorganisms (13). Recently, quite a number of these organisms were isolated from various habitats.

Species of Spirochaeta are quite common in anaerobic methanogenic communities in sewage sludge treatment systems. They are easily enriched from cultures of decomposing cellulosic material (3). Being common in mesophilic environments, Spirochaeta spp. have also recently been isolated from moderately extreme habitats. The first report of the isolation of spirochetes from an extreme environment was that of Patel et al., who isolated moderately thermophilic spirochetes from New Zealand hot springs (19). A thermal spring on the seashore in the tidal zone of the Kuryl Islands was the source of the thermophilic Spirochaeta thermophila (2). The same species was later isolated from a brackish hot spring in the Kermadec Islands $(1,22)$. A cyanobacterial mat in freshwater hot springs in Utah was the site of enrichment of "S. caldaria," an organism highly sensitive to $\mathrm{NaCl}$ and phylogenetically distant from $S$. thermophila (20). From the low-temperature environment of

\footnotetext{
* Corresponding author. Mailing address: Institute of Microbiology RAS, Prospect 60-let Octiabria, 7/2, 117811 Moscow, Russia. Electronic mail address: ZHILINA@IMBRAN.MSK.SU.
}

Ace Lake in Antarctica, a psychrophilic wall-less mycoplasmalike bacterium, strain DSM 6211, was isolated (8). Although it did not show typical spirochete morphology, this strain was shown to be phylogenetically related to the spirochetes (7). $S$. halophila was isolated from the hypersaline Solar Lake, a classical site for the halophilic biocoenosis of marine origin (10). All of the spirochetes previously described have been isolated from environments of neutral $\mathrm{pH}$.

Here, we describe three new alkaliphilic spirochetes from continental bodies of water which develop within anaerobic microbial communities of the extremely alkaline environments of soda lakes. The new isolates are characterized, and their phylogenetic positions among representatives of the order Spirochaetales are determined. The trophic structure of the anaerobic alkaliphilic community and isolation of spirochetes as well as the aim of the work were described previously $(28,30)$.

\section{MATERIALS AND METHODS}

Sampling. Samples were collected from the sediments of the alkaline lakes Magadi (East African Rift, Kenya) and Khatyn (Tuva, Russia). Lake Magadi is regarded as a classical site of modern soda deposition (6) and alkaliphilic microbial community development (24). From Lake Magadi, two samples taken in the dry period were studied, one from the cyanobacterial mat in a warm spring close to a causeway and the other from the dense bacterial bloom from under the trona layer in a shallow lagoon. Mud from Lake Khatyn ( $\mathrm{pH} \mathrm{10)}$ in the severe continental cryoarid climate region at Ulug-Khem Valley (Tuva) was delivered by V. C. Orleansky. Samples were collected anaerobically in rubber-stoppered bottles and were transported at ambient temperature to the laboratory, where they were maintained at $4^{\circ} \mathrm{C}$

Media and growth conditions. Enrichment of spirochetes was performed in alkaline medium II (30) containing (per liter) $15 \mathrm{~g}$ of $\mathrm{NaHCO}_{3}, 10 \mathrm{~g}$ of $\mathrm{Na}_{2} \mathrm{CO}_{3}$, and $10 \mathrm{~g}$ of $\mathrm{NaCl}$ with $5 \mathrm{~g}$ of starch as the substrate. Pure cultures were maintained in basic medium after the study of their physiology. The basic medium contains (per liter) $2 \mathrm{~g}$ of $\mathrm{Na}_{2} \mathrm{CO}_{3}, 4.5 \mathrm{~g}$ of $\mathrm{NaHCO}_{3}, 48 \mathrm{~g}$ of $\mathrm{NaCl}, 0.5 \mathrm{~g}$ of $\mathrm{NH}_{4} \mathrm{Cl}, 0.3 \mathrm{~g}$ of $\mathrm{KH}_{2} \mathrm{PO}_{4}, 0.001 \mathrm{~g}$ of resazurin, $0.5 \mathrm{~g}$ of yeast extract, $5 \mathrm{~g}$ of sucrose, $10 \mathrm{ml}$ of vitamin solution (26), $1 \mathrm{ml}$ of trace element solution (25), and $0.5 \mathrm{~g}$ of $\mathrm{Na}_{2} \mathrm{~S} \cdot 9 \mathrm{H}_{2} \mathrm{O}$ (final $\mathrm{pH}, 9$ ). Sucrose is a more convenient substrate than 
glucose, as no decomposition in the alkalic medium was observed after autoclaving at $110^{\circ} \mathrm{C}$ for $30 \mathrm{~min}$. Cultures were incubated at $37^{\circ} \mathrm{C}$ in an $\mathrm{N}_{2}$ atmosphere Routine transfers were performed with Bellco glass tubes and rubber-stoppered screw-cap flasks by a standard strictly anaerobic technique. Growth was recorded by optical density measurements at $600 \mathrm{~nm}$ in Bellco glass tubes using a photometer (Spekol, Jena, Germany) with the tube adapter ER.

Analytical procedures. Volatile products of glucose fermentation were quantified by using a Chrom-5 gas chromatograph equipped with a flame ionization detector, using argon as a carrier gas and a Chromosorb 101 column $(0.9 \mathrm{~m}$ by $3 \mathrm{~mm}$ ) at $160^{\circ} \mathrm{C}$. Lactate was identified by using a lactate dehydrogenase test kit (Boehringer Mannheim). Gaseous products were determined in an LHM-80 gas chromatograph with a catarometer using argon as a carrier gas and a molecularsieve $5 \mathrm{~A}$ column $(0.75 \mathrm{~m}$ by $3 \mathrm{~mm})$ at ambient temperature. Glucose was quantified by phenol- $\mathrm{H}_{2} \mathrm{SO}_{4}$ reaction (11).

Microscopy. The morphology of the living cultures was observed with an anoptral Reichardt Zetopan microscope.

Electron microscopy. Negative staining by phosphotungstate was performed after fixation with glutaraldehyde added to the culture at a final concentration of $2.5 \%$ ( $\mathrm{vol} / \mathrm{vol})$. Cells were centrifuged, resuspended in tap water, and stained with $1 \%(\mathrm{wt} / \mathrm{vol})$ phosphotungstate $(\mathrm{pH} 7)$. For ultrathin sectioning, cells were prefixed with glutaraldehyde in culture medium for $30 \mathrm{~min}$ at ambient temperature. The cells were centrifuged, washed once with $0.15 \mathrm{M} \mathrm{K}$-phosphate buffer $(\mathrm{pH} 7.2)$ with $3 \%(\mathrm{wt} / \mathrm{vol}) \mathrm{NaCl}$, and centrifuged, and the pellet was fixed with $1 \%(\mathrm{vol} / \mathrm{vol}) \mathrm{OsO}_{4}$ in acetate-Veronal buffer $(\mathrm{pH} 7.2)$ with $3 \%(\mathrm{wt} / \mathrm{vol}) \mathrm{NaCl}$ for $18 \mathrm{~h}$ at $4^{\circ} \mathrm{C}$. Dehydration and embedding in Epon 812 were done by standard methods. Microscopy was done with a JEM-100C microscope.

Genome characterization. DNA was isolated and purified from lysozyme- and sodium dodecyl sulfate-treated cells by the method of Marmur (16). The $\mathrm{G}+\mathrm{C}$ content was determined by a thermal denaturation method (17). Escherichia coli K-12 DNA was used as a standard. DNA-DNA hybridization was carried out by optical reassociation as described by De Ley et al. (4). The genome size was determined according to an equation in reference 9.

16S rRNA sequencing. Genomic DNAs were extracted from the three strains and the genes coding for $16 \mathrm{~S}$ rRNA (16S rDNAs) were amplified as described previously (21). PCR products were sequenced directly by using a Taq DyeDeoxy terminator cycle sequencing kit (Applied Biosystems) according to the manufacturer's instructions. The purified sequence reaction products were electrophoresed by using an Applied Biosystems model 373A DNA sequencer.

The sequences determined in this study were manually aligned with previously published sequences of representatives of the spirochetes. Pairwise evolutionary distances were computed by the correction of Jukes and Cantor (15). Phylogenetic analyses were carried out by using the algorithm of De Soete (5).

Nucleotide sequence accession number. The almost complete $(>95 \%$ of the $E$. coli sequence) $16 \mathrm{~S}$ rDNA sequences were determined for the three strains described here. The sequences have been deposited in the EMBL database under the following accession numbers: $S$. asiatica, X93926; S. alkalica, X93927; and $S$. africana, X93928.

\section{RESULTS}

Enrichment and isolation. Positive enrichments of spirochetes from the lake sediments were obtained in the alkaline medium with starch as the selective substrate. Glucose or other monosaccharides were nonselective, and rod-shaped organisms proliferate when these substrates are used. Spirochetes were enriched by filtration of the enrichment cultures through $0.45-\mu \mathrm{m}$-pore-size Millipore filters and subsequent serial dilutions in glucose-containing medium. Dilutions were repeated in appropriate stages of growth until cultures of uniform morphology were obtained. Softening of agar at high $\mathrm{pHs}$ limited the usefulness of solidified media in culture purification. Purity of the cultures was checked by microscopic examination of the growth in nonselective glucose- and peptone-containing medium. Purity was checked further during physiological studies of growth on a variety of substrates as well as during molecular studies. A single strain was chosen from each site for further studies: strain Z-7692 from a lagoon in Lake Magadi, strain Z-7491 from a warm spring in Lake Magadi, and strain Z-7591 from Lake Khatyn.

Morphology. All three strains are highly motile, with wavy movement and/or rotation. They have typical spirochetal structure (Fig. 1) and periplasmic flagella attached to the ends of a screw-shaped protoplasmic cylinder (Fig. 2). Strain Z-7692 has thin cells 0.25 to $0.3 \mu \mathrm{m}$ in diameter in the exponential phase and mainly 15 to 30 (occasionally 7 to 40 ) $\mu \mathrm{m}$ in length. Strain
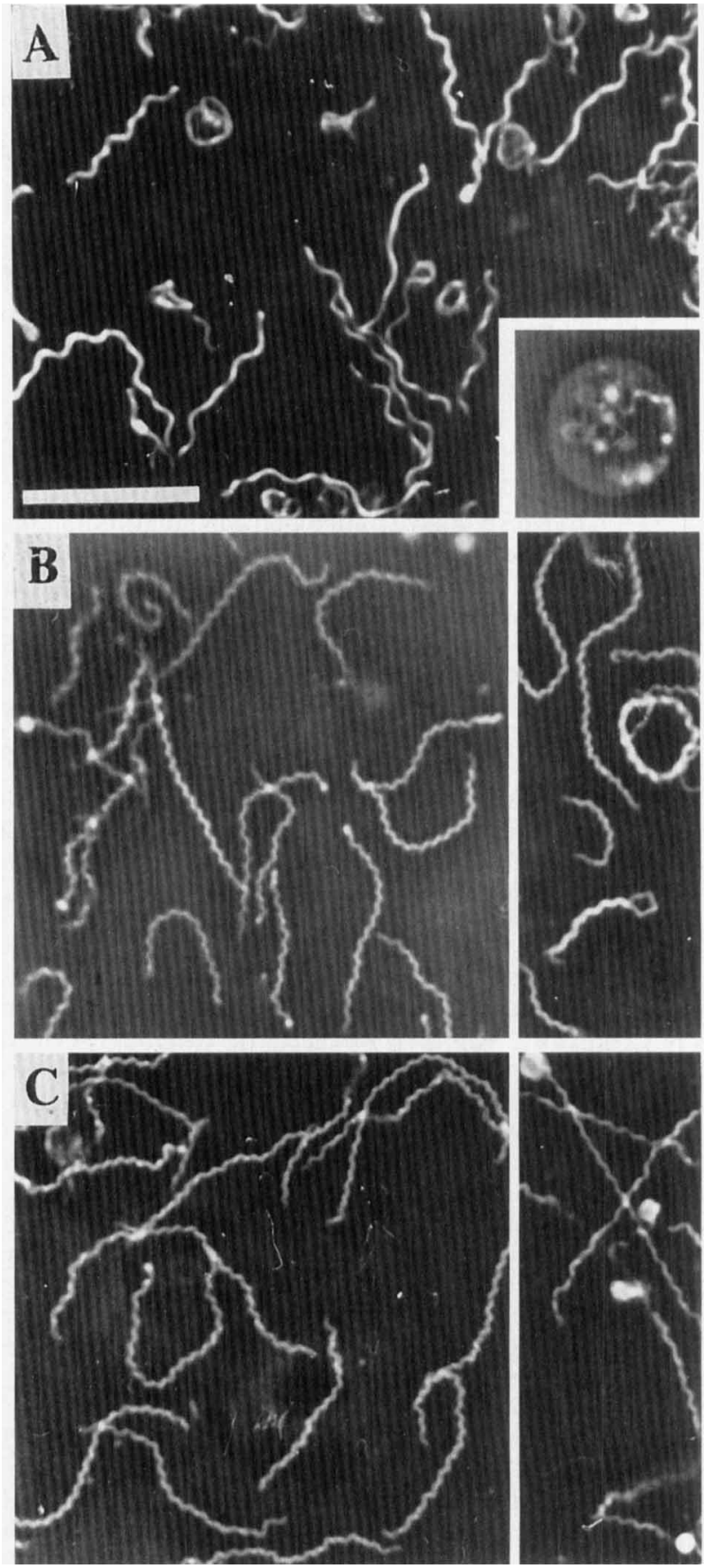

FIG, 1. Alkaliphilic spirochetes under an anoptral microscope in a wet mount. Bar, $10 \mu \mathrm{m}$. (A) $S$. alkalica Z-7491. Living normal cells and the beginning of spheroplast formation and curling into the clew are shown. Inset, large spherical body. (B) S. africana Z-7692. Living normal cells, hairpin formation, and spherical bodies on the cell ends are shown. (C) S. asiatica Z-7591. Thin delicate cells and formation of spherical bodies on the ends of the cells (insets) are shown.

Z-7491 has cells mostly 0.4 to $0.5 \mu \mathrm{m}$ in diameter and 9 to 18 $\mu \mathrm{m}$ in length, with a range of 6 to $35 \mu \mathrm{m}$. Cells of strain Z-7591 are thin, delicate, and transparent, 0.2 to $0.25 \mu \mathrm{m}$ in diameter, and mostly 15 to $20 \mu \mathrm{m}$ in length; however, short cells $(7.5 \mu \mathrm{m})$ were observed. In the late exponential phase, spherical bodies which dominate in the stationary phase or during dilution were observed (Fig. 1A). The type of spherical-body formation dif- 



FIG. 2. Negatively stained cells of alkaliphilic spirochetes. Bars, $0.5 \mu \mathrm{m}$. Typical structures with flagella in the periplasmic space are shown for $S$. alkalica Z-7491 (A), S. africana Z-7692 (B), and S. asiatica Z-7591 (C).

fered between strains. Strain Z-7692 forms hairpin or round bodies, strain Z-7491 begins to curl from one end into a clew surrounded by a joint outer membrane (Fig. 1A) resembling structures of Dictyoglomus turgidus (23), and under stressful conditions, strain Z-7591 either formed straight filaments or made a knot in the middle. Strains Z-7692 and Z-7591 under unfavorable conditions form spherical bodies on the tips.

The ultrastructure is typical of that described for Spirochaeta (3), with a large periplasmic space and periplasmic flagella wrapped around the protoplasmic cylinder. The cell wall has a typical gram-negative structure. In cross sections, localization of the flagellum is clearly seen (Fig. 3). When transferred into medium with low osmolarity, cells underwent lysis, the extent of which was strain dependent (data not shown).

Growth characteristics. All strains are mesophiles (Fig. 4) and moderate alkaliphiles (Fig. 5) and obligately depend on $\mathrm{Na}^{+}$ions (Fig. 6). No growth occurred without added $\mathrm{NaCl}$ in the medium when $\mathrm{Na}_{2} \mathrm{CO}_{3}$ was substituted by $\mathrm{K}_{2} \mathrm{CO}_{3}$. The two strains from Lake Magadi are similar in their growth characteristics, while strain Z-7591 from Lake Khatyn differs in having a lower $\mathrm{pH}$ and lower $\mathrm{NaCl}$ concentration maxima. For all strains, there is no growth below $\mathrm{pH} 8$, with an abrupt slope of the growth rate curve at lower pHs and a steep slope to higher $\mathrm{pHs}$ for the Lake Magadi strains.
The strains were found to differ in ion requirements. Only strain $\mathrm{Z}-7491$ grows in medium when the $\mathrm{Cl}^{-}$anion is omitted and the medium is supplemented by equimolar $\mathrm{Na}_{2} \mathrm{CO}_{3}+$ $\mathrm{NaHCO}_{3}$ instead of NaCl. For strains Z-7692 and Z-7591, $\mathrm{NaCl}$ is an essential component. When $\mathrm{Na}_{2} \mathrm{CO}_{3}+\mathrm{NaHCO}_{3}$ is substituted by $\mathrm{NaCl}$ and the $\mathrm{pH}$ is supported by $50 \mathrm{mM}$ serine buffer $\left(\mathrm{pK}_{\mathrm{a}} 9.2\right.$ ), only strain Z-7692 grows. On the basis of these characteristics, strain Z-7491 could be considered an alkaliphile, strain Z-7692 could be considered a halophile, and strain Z-7591 could be considered a haloalkaliphile. None of these strains had a requirement for the divalent cations $\mathrm{Mg}^{2+}$ and $\mathrm{Ca}^{2+}$.

The isolated strains are strictly saccharolytic and do not utilize amino acids. Each strain utilized pentoses, hexoses, and disaccharides with marked preferences (Table 1). In addition to these conventional substrates, alkaliphilic spirochetes could grow on some polysaccharides. All of them utilized starch; strain Z-7491 is agarolytic, strain Z-7692 utilized glycogen, and strain Z-7591 could grow slowly on xylan and pectin in addition to starch and glycogen. Used substrates arranged in the order of preference are given in diagnoses for each strain.

The three strains differ from one another in their metabolic products of glucose fermentation. S. alkalica Z-7491 forms acetate and hydrogen as the main products $(1.5$ and $1.7 \mathrm{~mol} /$ 


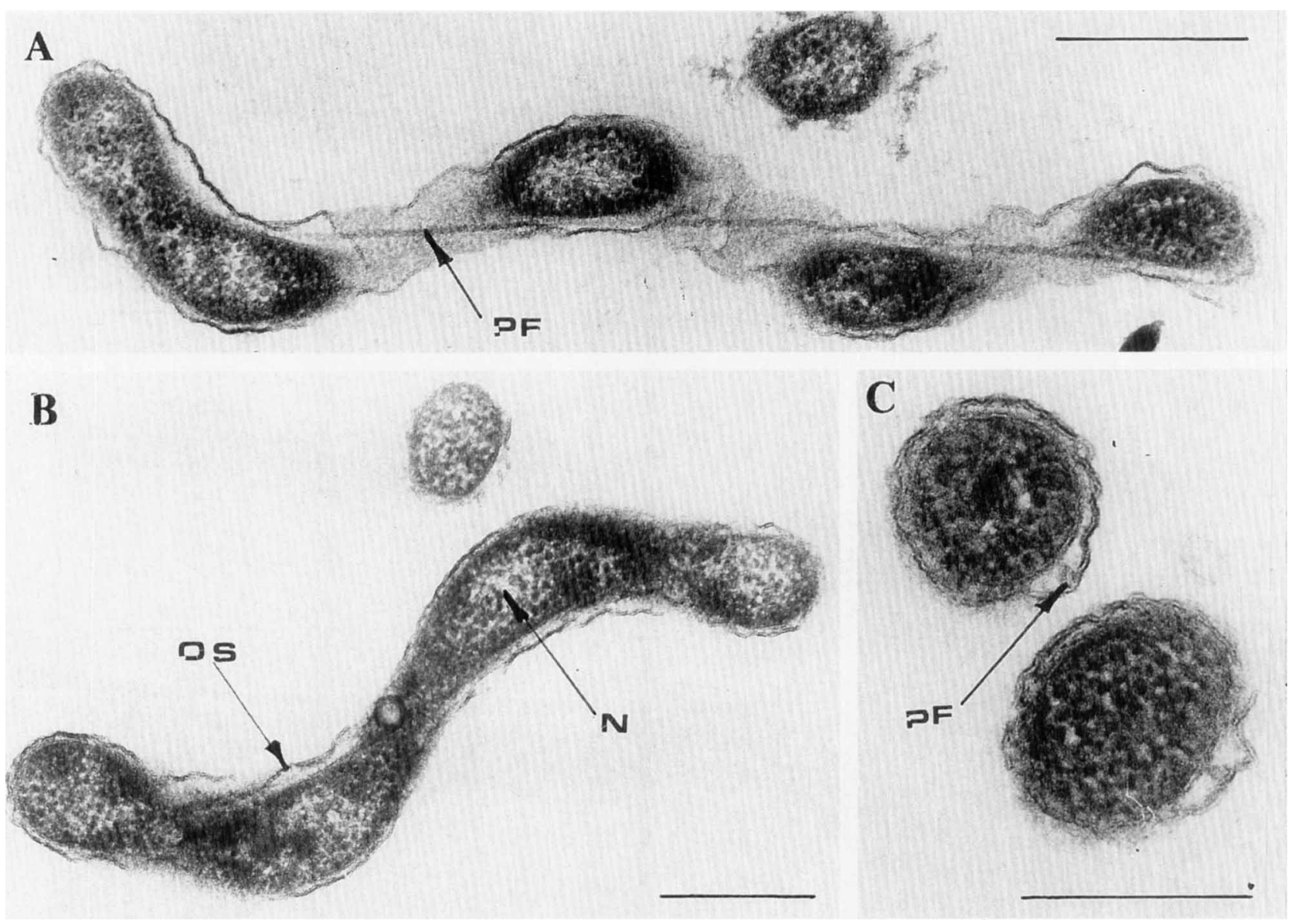

F1G. 3. Ultrastructure of $S$. alkalica as typical for alkaliphilic spirochetes. Bars, $0.5 \mu \mathrm{m}$. (A) Cross section with periplasmic flagella and tangential sections of cytoplasmic cylinder with polyribosomes and central DNA region. (B) Cross section with the central DNA region, flagellum, and structure of the outer membrane. (C) Transverse sections with flagella in the periplasmic space. PF, periplasmic flagellum; OS, outer sheath; N, nuclear region.

mol of glucose, respectively), while lactate and ethanol are formed as minor components in the stationary phase (6.8 and $2 \mathrm{mM}$, respectively). S. africana Z-7692 excretes acetate and ethanol as the main products $(1.1$ and $0.7 \mathrm{~mol} / \mathrm{mol}$ of glucose, respectively) and hydrogen and lactate as minor components ( 2.8 and $5 \mathrm{mM}$ in the stationary phase, respectively). S. asiatica Z-7591 decomposes glucose without formation of minor components, while the main products are acetate, ethanol, and lactate $(0.7,0.75$, and $0.4 \mathrm{~mol} / \mathrm{mol}$ of glucose, respectively).

The relationship of these organisms to oxygen also differs between strains. Strain Z-7591 is an obligate anaerobe. Strains Z-7692 and Z-7491 from Lake Magadi survived two or three transfers in glucose-containing medium under microaerobic conditions ( $5 \mathrm{ml}$ of medium in a tube under a cotton plug). Growth is weak, however; when the strain is inoculated back into anaerobic medium, normal growth is observed after a prolonged lag phase. Thus, the $\mathrm{H}_{2}$-producing spirochetes from Lake Magadi are aerotolerant, while the spirochete from Lake Khatyn is quite sensitive to oxygen.

Phylogenetic analysis. DNA-DNA homology studies indicated that there are significant differences between the strains (Table 2). The results indicate that all three strains represent distinct species.

The phylogenetic dendrogram (Fig. 7) shows the relationship of the alkaliphilic spirochetes to other spirochetes for which sequence data are available. All three strains group within the radiation of the majority of the species of the genus



FIG. 4. Effect of temperature on specific growth rate of alkaliphilic spirochetes. Basic medium (see Materials and Methods) was used. Below $20^{\circ} \mathrm{C}$, lag phases were more than 3 days. 


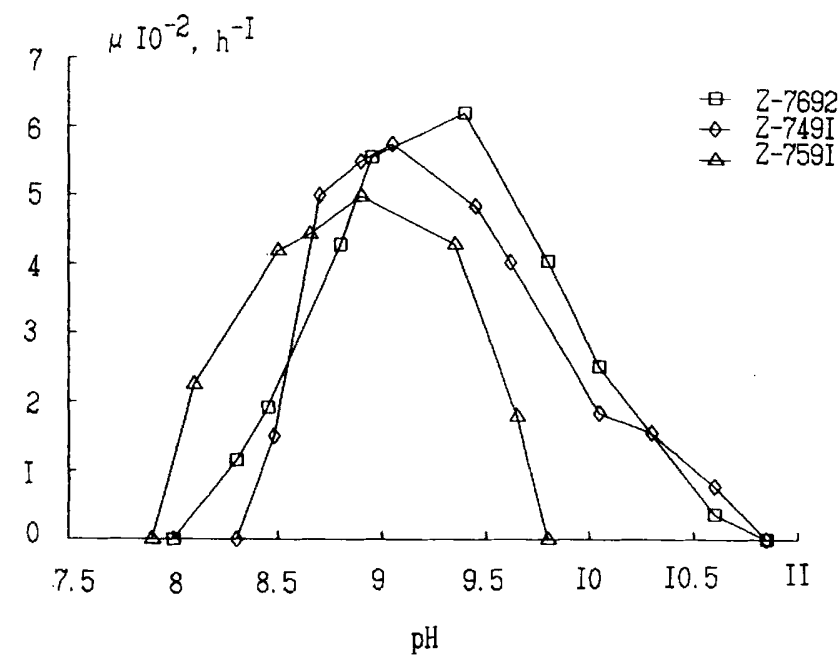

FIG. 5. Effect of $\mathrm{pH}$ on the specific growth rate of alkaliphilic spirochetes. Medium II without $\mathrm{Na}_{2} \mathrm{CO}_{3}$ was used, and the $\mathrm{pHs}$ shown were obtained by addition of $5 \mathrm{M} \mathrm{NaOH}$ in an anaerobic flask equipped with a $\mathrm{pH}$ electrode. Incubation was carried out at $35^{\circ} \mathrm{C}$.

Spirochaeta. The highest levels of $16 \mathrm{~S}$ rDNA similarity for the three strains are to S. halophila ( 89.2 to $94.5 \%$ ) (Table 3). Two strains, Z-7591 and Z-7692, group together at the level of $96.4 \% 16 \mathrm{~S}$ rDNA sequence similarity, while the third strain, Z-7491, clusters with $S$. halophila, showing $94.5 \%$ sequence similarity.

Taxonomic considerations. A comparison of the main differential traits for the alkaliphilic isolates and previously described marine Spirochaeta species is shown in Table 4. Both phenotypic and phylogenetic data indicate that the three spirochete strains isolated from extremely alkaline continental lakes are members of the genus Spirochaeta. These data, in combination with the DNA-DNA homology data, show them to represent three new species within the genus Spirochaeta. Three new species are proposed, with names derived from their ecophysiology and their place of origin: S. alkalica sp. nov., $S$. africana sp. nov., and $S$. asiatica sp. nov.

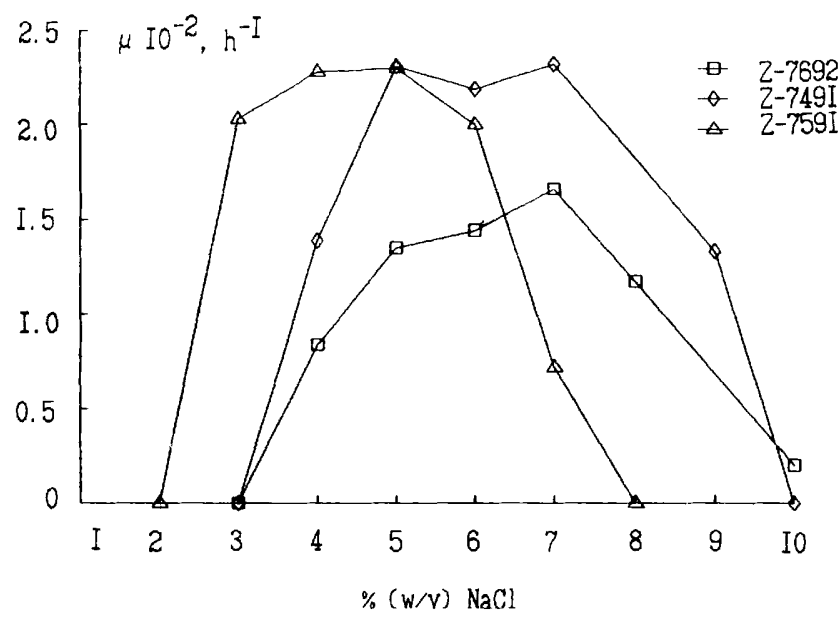

FIG. 6. Effect of $\mathrm{NaCl}$ on specific growth rate of alkaliphilic spirochetes. Medium II was used. $\mathrm{Na}_{2} \mathrm{CO}_{3}-\mathrm{NaHCO}_{3}$ was substituted by $5 \mathrm{~g}$ of $\mathrm{K}_{2} \mathrm{CO}_{3}$ per liter, and the final $\mathrm{pH}$ was brought up to 9 with concentrated $\mathrm{HCl}$. The reductant was $0.5 \mathrm{~g}$ of $\mathrm{K}_{2} \mathrm{~S}$ per liter. Incubation was carried out at $35^{\circ} \mathrm{C}$.
TABLE 1. Substrate utilization by alkaliphilic spirochetes

\begin{tabular}{lccc}
\hline \multirow{2}{*}{ Substrate } & \multicolumn{3}{c}{ Substrate utilization } \\
\cline { 2 - 4 } & S. alkalica & S. africana & S. asiatica \\
& Z-7491 & Z-7692 & Z-7591 \\
\hline Glucose & ++ & ++ & +++ \\
Mannose & - & + & ++ \\
Galactose & + & - & ++ \\
Xylose & ++ & + & + \\
Arabinose & + & - & + \\
Mannitol & - & - & + \\
Fructose & + & ++ & - \\
Ribose & + & - & - \\
$N$-Acetylglucosamine & + & - & - \\
Sucrose & ++ & ++ & +++ \\
Trehalose & ++ & ++ & +++ \\
Maltose & ++ & ++ & +++ \\
Cellobiose & ++ & ++ & ++ \\
Glycogen & - & ++ & +++ \\
Starch & ++ & ++ & +++ \\
Pectin & - & - & + \\
Xylan & - & - & + \\
Hydrolysis of agar & + & - & - \\
\hline
\end{tabular}

${ }^{a}+++$, final optical density at $600 \mathrm{~nm}\left(\mathrm{OD}_{600}\right)$ of 0.6 to 0.4 at stationary phase; ++ , final $\mathrm{OD}_{600}$ of 0.4 to $0.1 ;+$, final $\mathrm{OD}_{600}$ of 0.1 to 0.05 . The following substrates were not utilized by any of the alkaliphilic strains: raffinose, lactose, melibiose, erythritol, sorbose, tagatose, sorbitol, rhamnose, dulcitol, adonitol, inositol, acetate, pyruvate, Casamino Acids, lactate, glycerol, humic acids, Whatman paper no. 1, carboxymethyl cellulose, microcristalline cellulose, and peptone.

Description of Spirochaeta alkalica sp. nov. Spirochaeta alkalica (al.ka.li.ca, L. fem. adj. alkalica, of alkali, developing in the alkaline medium). Motile, helical cells, 0.4 to 0.5 by 9 to 18 $\mu \mathrm{m}$; shorter $(6-\mu \mathrm{m})$ and longer (up to $35-\mu \mathrm{m}$ ) cells occur in culture. The outermost structure is an outer membrane enclosing the periplasmic flagella and the protoplasmic cylinder. The cells have regular, stable primary coils. Cell mass is orange.

Alkaliphilic; growth in sodium carbonate medium optimally at $\mathrm{pH} 8.7$ to 9.6 . No growth at $\mathrm{pH} 8.3$ or 10.8 . Dependent on sodium; no growth below $3 \%$ (wt/vol) or above $10 \%(\mathrm{wt} / \mathrm{vol})$ $\mathrm{NaCl}$. Growth is possible when $\mathrm{NaCl}$ is substituted by equimolar $\mathrm{Na}_{2} \mathrm{CO}_{3}+\mathrm{NaHCO}_{3}$. Requires carbonate anion. Optimum temperature for growth, 33 to $37^{\circ} \mathrm{C}$; limits, 15 to $44^{\circ} \mathrm{C}$; slow growth at $6^{\circ} \mathrm{C}$ after a long lag phase.

Anaerobic, aerotolerant, fermentative; utilizes carbohydrates, mainly mono- and disaccharides, as carbon and energy sources. Preferred substrates are as follows: saccharose $>$ trehalose $>$ cellobiose $>$ glucose $=$ maltose $>$ xylose $>$ starch; poor growth with fructose, galactose, ribose, or $\mathrm{N}$-acetylglucosamine; no growth with mannose or glycogen.

Amylolytic and agarolytic. Amino acids do not serve as fermentable substrates. Aerotolerant; growth develops under a cotton plug in liquid medium.

The main products of glucose fermentation are acetate, $\mathrm{H}_{2}$,

TABLE 2. Genome characteristics of alkaliphilic Spirochaeta spp.

\begin{tabular}{lcccc}
\hline \multicolumn{1}{c}{ Strain } & $\begin{array}{c}\text { G+C } \\
\text { mol\% }\end{array}$ & $\begin{array}{c}\text { Genome size } \\
\left(10^{9}\right)\end{array}$ & \multicolumn{2}{c}{$\begin{array}{c}\text { DNA-DNA } \\
\text { homology (\%) }\end{array}$} \\
\cline { 4 - 5 } & & & Z-7491 & Z-7692 \\
\hline S. alkalica Z-7491 & 57.1 & 2.7 & 100 & \\
S. africana Z-7692 & 56.1 & 2.5 & 22 & 100 \\
S. asiatica Z-7591 & 49.2 & 2.1 & 14 & 10 \\
\hline
\end{tabular}




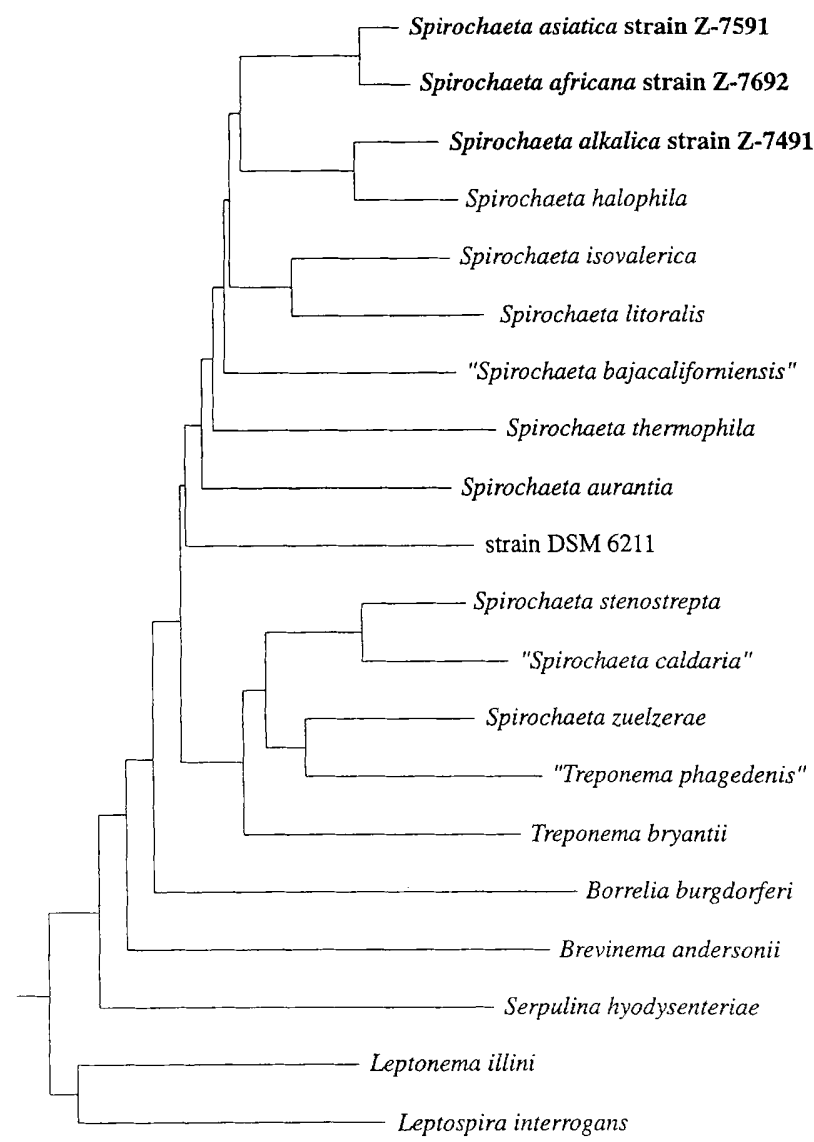

0.10

FIG 7. Phylogenetic dendrogram indicating the positions of the three alkaliphilic Spirochaeta species within the radiation of the spirochetes. Scale bar, 10 substitutions per 100 nucleotides. The root was determined by the inclusion of E. coli as an out-group organism.

and $\mathrm{CO}_{2}$. Minor products in stationary phase are ethanol and lactate.

A supplement of vitamins and yeast extract is required.

The guanine-plus-cytosine content of the DNA is $57.1 \mathrm{~mol} \%$ (thermal denaturation method).

Habitat: isolated from the cyanobacterial mat in the warm spring from under the horst in the equatorial alkaline Lake Magadi.

Type strain: Z-7491. Deposited with the Deutsche Sammlung von Mikroorganismen, DSM $8900^{\mathrm{T}}$.

Description of Spirochaeta africana sp. nov. Spirochaeta africana (af.ri.ca.na, L. fem. adj. africana, of African continent, found in African alkaline Lake Magadi). Motile, helical cells, 0.25 to 0.3 by 15 to $30 \mu \mathrm{m}$; shorter $(7.5-\mu \mathrm{m})$ and longer (up to $40-\mu \mathrm{m})$ cells occur in culture. The outermost structure is an outer membrane enclosing the periplasmic flagella and the protoplasmic cylinder. The cells have regular, stable primary coils. Cell mass is orange.

Halophilic, growing in sodium carbonate medium but not requiring it. Depends on sodium; no growth below 3\% (wt/vol) or above $10 \%$ (wt/vol) $\mathrm{NaCl}$. Optimal growth at $\mathrm{pH} 8.8$ to 9.75 . No growth at $\mathrm{pH} 8.0$ or 10.8. Optimum temperature for growth, 30 to $37^{\circ} \mathrm{C}$; range, 15 to $47^{\circ} \mathrm{C}$; slow growth at $6^{\circ} \mathrm{C}$ after




TABLE 4. Comparison of main traits of marine and alkaliphilic spirochetes

\begin{tabular}{|c|c|c|c|c|c|c|c|}
\hline Characteristic & $\begin{array}{l}\text { S. alkalica } \\
\text { Z-7491 }\end{array}$ & $\begin{array}{l}\text { S. africana } \\
\text { Z-7692 }\end{array}$ & $\begin{array}{c}\text { S. asiatica } \\
\text { Z-7591 }\end{array}$ & $\begin{array}{c}\text { S. halophila } \\
\text { RS-1 }{ }^{a}\end{array}$ & $\begin{array}{c}\text { S. isovalerica } \\
\text { MA-2 }^{b}\end{array}$ & $\begin{array}{l}\text { S. litoralis } \\
\qquad 1^{c}\end{array}$ & $\begin{array}{c}\text { S. thermophila } \\
\qquad \mathrm{Z}-1203^{i}\end{array}$ \\
\hline Cell diam $(\mu \mathrm{m})$ & $0.4-0.5$ & $0.25-0.3$ & $0.2-0.25$ & 0.4 & 0.4 & $0.4-0.5$ & $0.2-0.25$ \\
\hline Cell length $(\mu \mathrm{m})$ & $9-18$ & $15-30$ & $15-22.5$ & $15-30$ & $10-15$ & $5.5-7$ & $16-20$ \\
\hline Pigmentation ${ }^{\prime}$ & + & + & - & + & - & - & - \\
\hline Relationship to $\mathrm{O}_{2}$ & $\mathrm{FA}^{\prime}$ & FA & $\mathrm{OA}^{g}$ & FA & $\mathrm{OA}$ & OA & $\mathrm{OA}$ \\
\hline Temp $\left({ }^{\circ} \mathrm{C}\right)$ & $33-37$ & $30-37$ & $33-37$ & $35-40$ & $15-35$ & 30 & $66-68$ \\
\hline Growth at $\mathrm{pH}>8$ & + & + & + & $\mathrm{ND}^{h}$ & ND & - & - \\
\hline Optimum pH & $8.7-9.6$ & $8.8-9.75$ & $8.4-9.4$ & ND & ND & $7.0-7.5$ & 7.5 \\
\hline Optimum $\mathrm{NaCl}(\mathrm{M})$ & $0.75-1.4$ & $0.8-1.4$ & $0.5-1.4$ & $0.5-1$ & $0.2-0.3$ & 0.35 & 0.25 \\
\hline $\mathrm{YE}^{i}$ requirement & + & - & + & + & - & - & - \\
\hline $\mathrm{G}+\mathrm{C}$ content $(\mathrm{mol} \%)$ & 57 & 56 & 49 & 62 & 64.5 & 50.5 & 52 \\
\hline \multicolumn{8}{|l|}{ Products from glucose: } \\
\hline $\mathrm{H}_{2}$ & + & + & - & + & + & + & + \\
\hline Acetate & + & + & + & + & + & + & + \\
\hline Ethanol & $+1-$ & + & + & + & + & + & - \\
\hline Lactate & $+1-$ & $+1-$ & + & $+1-$ & $+1-$ & - & - \\
\hline
\end{tabular}

${ }^{a}$ Data from reference 10.

${ }^{b}$ Data from reference 12.

c Data from reference 14.

"Data from reference 2.

'For our strains, pigmentation given for cell mass (+, pigmented; - - , nonpigmented).

${ }^{f} \mathrm{FA}$, facultative anaerobe.

${ }^{g} \mathrm{OA}$, obligate anaerobe.

${ }^{h} \mathrm{ND}$, not determined.

${ }^{i} \mathrm{YE}$, yeast extract.

${ }^{j}$ On glucose plus yeast extract complex medium.

a long lag phase. Aerotolerant; develops under a cotton plug in liquid medium.

Anaerobic, aerotolerant, fermentative; utilizes carbohydrates, mainly mono- and disaccharides, as carbon and energy sources. The order of preference is as follows: fructose $>$ maltose $=$ trehalose $=$ saccharose $>$ cellobiose $>$ glucose $>$ glycogen $>$ starch; poor growth with mannose or xylose; no growth with galactose, $N$-acetylglucosamine, or ribose. Amino acids do not serve as fermentable substrates.

The main products of glucose fermentation are acetate, ethanol, and $\mathrm{H}_{2}$. The minor product in stationary phase is lactate.

A supplement of vitamins is required; however, yeast extract can be omitted for strain Z-7692.

The guanine-plus-cytosine content of the DNA is $56.1 \mathrm{~mol} \%$ (thermal denaturation method).

Habitat: isolated from bacterial bloom in the brine under trona from alkaline equatorial Lake Magadi.

Type strain: Z-7692. Deposited with the Deutsche Sammlung von Mikroorganismen, DSM $8902^{\mathrm{T}}$.

Description of Spirochaeta asiatica sp. nov. Spirochaeta asiatica (asi.ati.ca, L. fem. adj. asiatica, from the Asian continent, in the central part of which the organism was found).

Motile, helical cells, 0.2 to 0.25 by 15 to $22.5 \mu \mathrm{m}$; shorter $(7.5-\mu \mathrm{m})$ cells occur in culture. The outermost structure is an outer membrane enclosing the periplasmic flagella and the protoplasmic cylinder. The cells have regular, nonstable primary coils. Round bodies which are usually nonviable are formed at the end of the growth period. Nonpigmented.

Haloalkaliphilic; growth in soda solution at optimal $\mathrm{pH} 8.4$ to 9.4 with limits $\mathrm{pH} 7.9$ to 9.7 . Growth is $\mathrm{Na}$ dependent; no growth below $2 \%$ (wt/vol) $\mathrm{NaCl}$ or above $8 \%(\mathrm{wt} / \mathrm{vol}) \mathrm{NaCl}$; optimum, 3 to $6 \%$ (wt/vol) $\mathrm{NaCl}$. Requires carbonate anion. Broad thermal adaptation with prolonged lag phase; optimum at 33 to $37^{\circ} \mathrm{C}$, limits at 20 to $43^{\circ} \mathrm{C}$.

Strictly anaerobic, fermentative, utilizes simple and complex carbohydrates. The order of preference is as follows: glucose $>$ maltose $>$ glycogen $>$ mannose $>$ trehalose $>$ cellobiose $>$ saccharose $>$ starch $>$ galactose $>$ pectin $>$ xylane; poor growth with xylose or arabinose; no growth with fructose, ribose, lactose, agar, or $\mathrm{N}$-acetylglucosamine. Amino acids are not fermented.

Fermentation products from glucose include acetate, ethanol, and lactate; $\mathrm{H}_{2}$ not produced.

A supplement of vitamins is required, and yeast extract enhances growth.

The guanine-plus-cytosine content of the DNA is $49.2 \mathrm{~mol} \%$ (thermal denaturation method).

Habitat: isolated from the mud of alkaline Lake Khatyn in Tuva, Central Asia.

Type strain: Z-7591. Deposited with the Deutsche Sammlung von Mikroorganismen, DSM $8901^{\mathrm{T}}$.

\section{DISCUSSION}

Soda lakes are formed by evaporation of continental carbonate-containing waters produced by the leaching of rocks by $\mathrm{CO}_{2}$-containing meteoric or thermal water. Depending on the rock composition, $\mathrm{Na}$ - or $\mathrm{Ca}$-dominated waters are produced by the hydrolysis of silicates. Athalassic habitats essentially differ from thalassic ones and presumably might contain organisms from different origins (28).

Continental bodies of alkaline water harbor quite diverse microbial communities capable of completely decomposing organic matter. The usual prime producers in these habitats are cyanobacteria; however, green algae also proliferate in soda lakes. This differentiates continental bodies of water from marine habitats, in which cyanobacteria and green algae are in the minority. Green algae produce cellulosic material. Decomposition of cellulose occurs in alkaline lakes, and extremely alkaliphilic anaerobic cellulose-decomposing bacteria have been reported (30). Spirochaeta spp. are typical representatives of the functional group of dissipotrophs. It has for a long time 
been recognized that Spirochaeta strains are active in the fermentation of sugars formed by the enzymatic activity of polysaccharide-degrading microorganisms (13). Only rarely can spirochetes from the original bacterial bloom in the soda lakes be observed by direct microscopy; however, they are easily enriched by using starch-containing media. Trophically linked members in the community usually are representatives of phylogenetically unrelated groups (27). The genus Spirochaeta, which represents a distinct phylogenetic lineage, provides a good example of this type of relationship, being a trophical intermediate between hydrolytic bacteria and secondary anaerobes. These organisms produce compounds which are normally consumed by sulfate-reducing bacteria. However, we have as yet been able to isolate only an $\mathrm{H}_{2}$-consuming sulfate reducer and not lactate- or acetate-utilizing species from the sulfide sediments in Lake Magadi.

Thermophilic spirochetes differ from each other in their salt requirements: $S$. thermophila, from a marine origin, needs 0.5 to $4.5 \% \mathrm{NaCl}(1,2)$, while "S. caldaria," from the continental hot spring in Utah, does not tolerate $0.4 \% \mathrm{NaCl}(20)$. Also, the continental strains are distinct from each other (Table 4). Alkaliphilic spirochetes from continental bodies of water belong to the same phylogenetic cluster as marine forms, and thus it is not possible to discriminate between thalassic and athalassic groups. The spirochetes of marine origin fall within one phylogenetic cluster, while $S$. stenostrepta, $S$. zuelzerae, and " $S$. caldaria," spirochetes of freshwater origin, group with the Treponema species. The freshwater spirochete $S$. aurantia is an exception to this observation in that it groups with the marine spirochetes, albeit deeply within the phylogenetic cluster. The previously described Spirochaeta species have relatively low levels of $16 \mathrm{~S}$ rDNA sequence similarity to each other (81.6 to $93.1 \%$ ) (Table 3). The high degree of similarity at the $16 \mathrm{~S}$ rDNA sequence level (96.4\%) between $S$. asiatica and $S$. africana, complemented by a low level of DNA-DNA homology $(10 \%)$, indicates the possible fanning out of the phylogenetic tree as more branches are added when new Spirochaeta species are discovered and investigated.

The description of three new, extremely alkaliphilic spirochetes broadens understanding of both the diversity of the genus Spirochaeta and the role of this peculiar group in extreme environments.

\section{ACKNOWLEDGMENTS}

G. A. Zavarzin acknowledges full-hearted help from the members of the Russian Embassy to Kenya. The hospitality of the International Ubsu-Nur Biospheric Center is appreciated.

This research was partly supported by project "Biodiversity of extremophilic prokaryotae" from Russian State Scientific Program "Biodiversity" and by grant 68000 from the International Science Foundation.

\section{REFERENCES}

1. Aksenova, E. Y., F. A. Rainey, P. H. Janssen, G. A. Zavarzin, and H. W. Morgan. 1992. Spirochaeta thermophila sp. nov., an obligately anaerobic, polysaccharolytic, extremely thermophilic bacterium. Int. J. Syst. Bacteriol. 42:175-177.

2. Aksenova, E. Y., V. A. Svetlichny, and G. A. Zavarzin. 1990. Spirochaeta thermophila sp. nov.: a thermophilic marine spirochete isolated from a littoral hydrotherm of Shiashkotan Island. Microbiology 59:735-741.

3. Canale-Parola, E. 1992. Free-living saccharolytic spirochetes: the genus Spirochaeta, p. 3524-3536. In A. Balows, H. G. Truper, M. Dworkin, W:
Harder, and K.-H. Schleifer (ed.), The prokaryotes: a handbook on the biology of bacteria. Ecophysiology, isolation, identification, applications, vol. IV. Springer-Verlag Inc., New York.

4. De Ley, J., H. Cattoir, and A. Reynaerts. 1970. The quantitative measurement of DNA hybridization from renaturation rates. Eur. J. Biochem. 12: 133-142.

5. De Soete, G. 1983. A least square algorithm for fitting additive trees to proximity data. Psychometrika 48:621-626.

6. Eugster, H. P. 1980. Lake Magadi, Kenya, and its precursors, p. 195-232. In A. Nissenbaum (ed.), Hypersaline brines and evaporitic environments. Developments in sedimentology. Elsevier Scientific Publishing Co., Amsterdam.

7. Franzmann, P. D., and S. J. Dobson. 1992. Cell wall-less, free-living spirochetes in Antarctica. FEMS Microbiol. Lett. 97:289-292.

8. Franzmann, P. D., and M. Rohde. 1992. Characteristics of a novel, anaerobic, mycoplasma-like bacterium from Ace Lake, Antarctica. Antarctic Sci. 4: 155-162.

9. Gillis, M., J. De Ley, and M. De Cleene. 1970. The determination of molecular weight of bacterial DNA from renaturation rates. Eur. J. Biochem. 12: 143-153.

10. Greenberg, E. P., and E. Canale-Parola. 1976. Spirochaeta halophila sp. n., a facultative anaerobe from a high-salinity pond. Arch. Microbiol. 110:185194.

11. Hansson, R., and J. Phillips. 1981. Chemical composition, p. 328-364. In P. Gerhardt, R. G. E. Murray, R. N. Costilow, E. W. Nester, W. A. Wood, N. R. Krieg, and G. B. Phillips (ed.), Manual of methods for general bacteriology. American Society for Microbiology, Washington, D.C

12. Harwood, C. S., and E. Canale-Parola. 1983. Spirochaeta isovalerica sp. nov., a marine anaerobe that forms branched-chain fatty acids as fermentation products. Int. J. Syst. Bacteriol. 33:573-579.

13. Harwood, C. S., and E. Canale-Parola. 1984. Ecology of spirochetes. Annu. Rev. Microbiol. 38:161-192.

14. Hespell, R. B., and E. Canale-Parola. 1970. Spirochaeta litoralis sp. n., a strictly anaerobic marine spirochete. Arch. Mikrobiol. 74:1-18.

15. Jukes, T. H., and C. R. Cantor. 1969. Evolution of protein molecules, p. 21-132. In H. N. Munro (ed.), Mammalian protein metabolism. Academic Press, Inc., New York.

16. Marmur, J. 1961. A procedure for the isolation of deoxyribonucleic acid from microorganisms. J. Mol. Biol. 3:208-218.

17. Owen, R. J., L. R. Hill, and S. P. Lapage. 1969. Determination of DNA base compositions from melting profiles in dilute buffers. Biopolymers 7:503-516.

18. Paster, B. J., F. E. Dewhirst, W. G. Weisberg, L. A. Tardoff, G. J. Fraser, R. B. Hespell, T. B. Stanton, L. Zablen, L. Mandelco, and C. R. Woese. 1991. Phylogenetic analysis of the spirochetes. J. Bacteriol. 173:6101-6109.

19. Patel, B. K. C. H. W. Morgan, and R. M. Daniel. 1985. Thermophilic anaerobic spirochetes in New Zealand hot springs. FEMS Microbiol. Lett. 26:101-106.

20. Pohlschroeder, M., S. B. Leschine, and E. Canale-Parola. 1994. Spirochaeta caldaria sp. nov., a thermophilic bacterium that enhances cellulose degradation by Clostridium thermocellum. Arch. Microbiol. 161:17-24.

21. Rainey, F. A., M. Dorsch, H. W. Morgan, and E. Stackebrandt. 1992. 16S rDNA analysis of Spirochaeta thermophila: its phylogenetic position and implications for the systematics of the order Spirochaetales. Syst. Appl. Microbiol. 15:197-202.

22. Rainey, F. A., P. H. Janssen, and D. J. C. Wild. 1991. Isolation and characterization of an obligately anaerobic, polysaccharolytic, extremely thermophilic member of the genus Spirochaeta. Arch. Microbiol. 155:396-401.

23. Svetlichny, V. A., and T. P. Svetlichnaya. 1988. Dictyoglomus turgidus $\mathrm{sp}$ nov., a new extreme thermophilic eubacterium isolated from hot springs of the Uzon volcano crater. Microbiology 57:435-441.

24. Tindall, B. J. 1988. Procaryotic life in the alkaline, saline athalassic environment, p. 31-67. In F. Rodriguez-Valera (ed.), Halophilic bacteria, vol. 1. CRC Press, Boca Raton, Fla.

25. Whitman, W. B., E. Ankwanda, and R. S. Wolfe. 1982. Nutrition and carbon metabolism of Methanococcus voltae. J. Bacteriol. 149:852-863.

26. Wolin, E. A., M. J. Wolin, and R. S. Wolfe. 1963. Formation of methane by bacterial extracts. J. Biol. Chem. 238:2882-2886.

27. Zavarzin, G. A. 1989. Microbial community in the past and the present Microbiol. Zhurn. (Kiev) 51:3-14. (In Russian.)

28. Zavarzin, G. A. 1993. Epicontinental soda lakes as probable relict biotopes of terrestrial biota formation. Microbiology 62:473-479.

29. Zavarzin, G. A. 1993. An ecological approach to the systematics of procaryotes, p. 555-558. In R. Guerrero and C. Pedros-Alio (ed.), Trends in microbial ecology. Spanish Society for Microbiology, Barcelona.

30. Zhilina, T. N., and G. A. Zavarzin. 1994. Alkaliphilic anaerobic community at $\mathrm{pH}$ 10. Curr. Microbiol. 29:109-112. 